УДК 323.28

https://doi.org/10.34142/24130060.2020.21.2.03

\title{
ТЕРОРИЗМ У СУЧАСНОМУ СУСПІЛЬСТВІ: ОСНОВНІ ПОНЯТТЯ ТА ХАРАКТЕРИСТИКИ
}

\author{
Ю. А. Данько, Н. Г. Білоцерківська
}

Харківський національний педагогічний університет імені Г.С. Сковороди

У статті наголошується, щзо тероризм у сучасному світі представляє все більшу загрозу громадській і національній безпеці краӥн. Наведені різні погляди на визначення поняття «тероризму». Розглянуте трактування тероризму у різних країнах світу, зокрема США, Британії та Свропейському Союзі. Зазначено, щзо він в сучасному світі має політичне забарвлення, так як він, перш за все, пов'язаний з владою.

Розглянуто основні види тероризму, серед яких політичний, національний, релігійний та інформаційний. Також розглянуто основні ияілі тероризму та політичні причини тероризму.

Ключові слова: тероризм, міжнародний тероризм, терористичні організації, політичний тероризм, національний тероризм, релігійний тероризм, інформаційний тероризм, глобалізачія.

\section{ТЕРРОРИЗМ В СОВРЕМЕННОМ ОБЩЕСТВЕ: ОСНОВНЫЕ ПОНЯТИЯ И ХАРАКТЕРИСТИКИ}

\author{
Ю. А. Данько, Н. Г. Белоцерковская
}

В статье отмечается, что терроризм в современном мире представляет все большую угрозу общественной и начиональной безопасности стран. Приведень различные взгляды на определение понятия «терроризма». Рассмотрены трактовки терроризма в различных странах мира, включая США, Великобританию и Европейский Союз. Указано, что он в современном мире имеет политическую окраску, так как он, прежде всего, связан с властью.

Рассмотрены основные виды терроризма, среди которых политический, национальный, религиозный и информационный. Также рассмотреньл основные цели терроризма и политические причины терроризма.

Ключевые слова: терроризм, международный терроризм, террористические организачии, политический терроризм, национальный терроризм, религиозный терроризм, информационный терроризм, глобализация.

\section{TERRORISM IN MODERN SOCIETY: BASIC CONCEPTS AND CHARACTERISTICS}

\section{Y. Danko, N. Bilotserkivska}

The article emphasizes that terrorism in the modern world poses an increasing threat to public and national security. There are different views on the definition of "terrorism". Terrorism can be defined as a method of influence by committing a terrorist act to achieve 
certain goals. The interpretation of terrorism in different countries of the world, in particular the USA, is considered The U.S. Department of State treats terrorism as any act of political violence by non-state actors or "secret government agents," and U.S. law defines a terrorist act as criminal violence that is intended to intimidate or force civilians to influence politics. government through intimidation or coercion), Britain (terrorism is the use of force to achieve political goals, which includes any use of violence) and the European Union (terrorism is classified as "an internationally condemned act committed by an individual or group against one or more countries, their institutions or citizens, to intimidate and fundamentally change or destroy the political, economic or social structures of the state"). It is noted that in the modern world it has a political color, as it is primarily associated with power. It is determined that the main purpose of terrorism is to achieve certain political, religious, or other social changes.

The main types of terrorism are considered, including political (has two directions: the struggle of various groups against the existing system; state terrorism carried out by state special services), national (method of struggle of peoples to create their own state), religious (based on religious fanaticism) and information ( a new kind of terrorism, operates in the intellectual sphere and generates a new kind of violence). Terrorism can often develop in times of socio-political and economic crises. The main goals of terrorism and political causes of terrorism are also considered. One of the main prerequisites for modern terrorism is the resonance of terrorist action in society.

Key words: terrorism, international terrorism, terrorist organizations, political terrorism, national terrorism, religious terrorism, information terrorism, globalization.

Постановка проблеми. Проблема тероризму в сучасному світі одна 3 найбільш актуальних, вона стала об’єктом підвищеної уваги для представників наукових кіл, світових лідерів, представників політичних еліт і громадськості загалом.

3 другої половині XX століття міжнародний тероризм набув реальної загрози для усієї світової спільноти, став серйозною соціальноекономічною небезпекою та вагомим чинником посилення міжнародного напруження, масштаби якого стали настільки значними, що вже йдеться про реальну небезпеку не тільки для окремої держави, а й для усього світового співтовариства в цілому.

Занепокоєння світової спільноти через зростання терористичної активності пояснюється великою кількістю жертв i величезними матеріальними втратами. Останнім часом жертвами терористичної діяльності все частіше ставати жителі таких країн як США, Франції, Іспанії, Росії, Пакистану, Ізраїлю, Сгипту, Туреччини, Сирії, Ірану та ряду інших країн. Терористична діяльність в нинішній час характеризується широким розмахом своєї діяльності, відсутністю явно виражених кордонів, 
наявністю зв’язку і з міжнародними терористичними організаціями і їх центрами (Gorbatenkov, 2018).

Тероризм у будь-якій країні завдає шкоди конституційному ладу, підриває стабільність політичного курсу, стійкість політичної системи, створює перешкоди на шляху реалізації прав i свобод людини та громадянина. Тому пошук нових можливостей для протидії терористичним актам потребує досить складних та багатопланових завдань (ідеологічного і фізичного характеру) (Туmoshenko, 2017, s. 289).

Аналіз актуальних досліджень. Тероризм у різний його аспектах досліджувався у працях зарубіжних дослідників: Г. Ангейєра, Р. Бейснера, Д. Белла, І. Валлерстайна, А. Гарфінкла, М. Гласіуса, С. Гука, П. Девіса, Б. Дженкіса, Р. Кагана, М. Келдора, А. Конте, С. Купчана, Д. Пайпса, В. Подгореца, Р. Родмена, Дж. Спеніера, Дж. Торопа, С. Хантінгтона, Р. Хантера, К. Хіршмана, С. Хоффмана.

В Україні серед досліджень цієї проблеми слід відзначити роботи
В. Антипенка,
Т. Бояр-Созановича,
В. Глушкова,
В. Смельянова,
В. Тихого.

Наукову зацікавленість політичний тероризм викликає у дослідників
В. Бушанського,
О. Бардіна,
А. Деменко,
О. Дзьобань,
М. Лазарєва, О. Максимова, О. Половко, М. Требіна. Дослідженням міжнародного тероризму i наслідками його деструктивних дій займалися М. Гуцало,
В. Канцір,
В. Крутов,
В. Ліпкан,
В. Антипенко,
I. Трунов, Дж. Розі, С. Розен.

Метою статті $\epsilon$ дослідження змісту та основних характеристик феномена тероризму в сучасному суспільстві.

Виклад основного матеріалу. Тероризм як явище має глибокі історичні корені. Його історія нараховує стільки ж років, скільки і історія людської цивілізації, адже поява тоталітарних або демократичних співтовариств однаково так чи інакше породжувала терористичні явища. 
У науковій літературі $є$ різні погляди на визначення поняття «тероризму». Проте усі дослідники одностайні стосовно важливості визначення цього феномену.

Отже тероризм можна визначити як метод впливу шляхом здійснення теракту за для досягнення певних цілей, за якого жертва теракту не $є$ об’єктом (Riumina, 2011, s. 266). Тероризм також визначають як метод за допомогою якого організована група або партія прагне досягти проголошених нею цілей переважно через систематичне використання насильства.

Американський політолог Ф. Хейманн вважає, що тероризм це «політичне насильство всередині або проти справжніх демократій».

П. Вілкінсон також підкреслює політичну мету тероризму, відзначаючи, що це, перш за все, «систематичне і навмисне використання насильства для створення атмосфери страху з політичними цілями.

С. Комбс визначає тероризм як «синтез війни і театру, драматизацію найбільш забороненого виду насильства - насильства, призначеного для невинних жертв, - розігрується перед аудиторією в розрахунку на створення настрою страху, з політичними цілями» (Luppov, 2009).

Як зазначає Д. Ольшанський, сучасний тероризм «відрізняється від всіх які зустрічалися в історії масовістю своїх жертв i складним, міждержавним i наднаціональним характером. ... Безперервно ускладнюється характер тероризму, наростає витонченість його методів, посилюється антигуманність терористичних актів, що набувають все більш масовий i, внаслідок цього, жорстокий характер» (Olshanskiy, 2002).

У США діє відразу кілька визначень тероризму. Державний департамент США розглядає в якості тероризму будь-який акт насильства в політичних цілях з боку недержавних акторів або «секретних державних агентів» зазвичай щодо цивільних осіб з метою вплинути на громадськість. Американське законодавство визначає як терористичний акт злочинне насильство, яке виявляється призначеним для того, щоб залякати або 
примусити цивільне населення вплинути на політику уряду шляхом залякування чи примусу або впливати на поведінку уряду вбивством або викраденням».

Відповідно до британського закону про запобігання тероризму, останній варіант якого був прийнятий в 2006 році, тероризм - «це використання сили для досягнення політичних цілей, що включає в себе будь-яке застосування насильства 3 метою залякати громадськість або іiі частину».

У Свропейському Союзі тероризм кваліфікується як «міжнародно засуджений акт, вчинений окремою особою або групою проти одного або декількох країн, їх інститутів або громадян, 3 метою налякати i фундаментально змінити або знищити політичні, економічні чи соціальні структури держави» (Luppov, 2009, s. 944).

Термін «тероризм» в сучасному світі має більшою мірою політичне забарвлення, так як він, перш за все, пов’язаний з владою: гонитва за владою, придбання влади i використання ii для досягнення політичних змін.

У сучасному світі виділяється кілька видів тероризму:

1. Політичний тероризм. Цей вид тероризму має два напрямки. 3 одного боку, це боротьба різних угруповань проти існуючого ладу («Червоні бригади» в Італії, «Об’єднана червона армія» в Японії, «Аксьонов директ» у Франції, у Німеччині - «Група Біадера-Майнкоф», «Рух другого червня», «революційні осередки»). 3 іншого боку, це державний тероризм, який здійснюється державними спецслужбами. Подібні методи спецслужби використовували i використовують для знищення державних ворогів. Такі акції здійснювали КДБ СРСР, ЦРУ США, «Массад» Ізраїлю (Kantsir, 2010, s. 269).

2. Національний тероризм - це метод боротьби народів за створення власної держави (народи, що не мають власної держави, вимагають незалежності і беруться за зброю). До національного тероризму можна 
віднести боротьбу басків, які проживають в Південній Франції і Північної Іспанії, боротьбу IPA (Ірландської республіканської армії), яка за допомогою терактів у Великобританії намагається домогтися незалежності Північної Ірландії.

3. Релігійний тероризм - це найнебезпечніший вид тероризму, заснований на релігійному фанатизмі. Тут можна відзначити боротьбу палестинців проти Ізраїлю, події у США (Kantsir, 2015).

4. Інформаційний тероризм. Новий різновид тероризму, відрізняється від інших тим, що діє в інтелектуальній сфері й породжує новий вид насильства, яке може бути спрямоване проти кого завгодно (Shachkovs'ka ta Khudajkulova, 2017, s. 118). Інформаційний тероризм - це форма негативного впливу на особистість, суспільство і державу з використанням різних видів інформації. Він може вестися як іноземними спецслужбами так закордонними і вітчизняними ЗМI, здійснюється для психологічного терору 3 використанням не лише друковані ЗМІ та мережі ефірних й кабельних телеканалів, але й Інтернету та електронної пошти (Riumina, 2011, s. 267).

Тероризм найчастіше може розвиватися в періоди соціальнополітичних та економічних криз. На думку американського філософа, соціолога i політолога I. Валлерстайна - «значною мірою в глобалізованому світі причини тероризму пов'язані 3 диспропорцією міжнародного розподілу капіталу та глобалізацією бідності в країнах третього світу, що призводить до розширення соціальної бази тероризму, також сприяє формуванню соціального підгрунтя цього явища маргіналізація та криміналізація населення. Несприйняття процесів глобалізації стає сприятливим середовищем для виникнення міжнародного тероризму» (Tymoshenko, 2017, s. 292).

Як свідчать результати досліджень міжнародних антитерористичних організацій, спецслужб різних країн, сьогодні найбільшу світову терористичну загрозу несуть ісламістські або джихадистські організації та 
групи. До яких належать «Ісламська держава» (раніше «ІДІЛ» - Ісламська держава Іраку та Ліванту), палестинський рух «ХАМАС», «Адь-Каїда», Бригади мучеників Аль-Акси, Абу Сайяф на Філіппінах, Аль-Джихад у Єгипті, Аль-Харамейн у Саудівській Аравії, Армія звільнення Аден-Абійя у Ємені, Бойова ісламська група у Лівії, Озброєна Ісламська Група та багато інших (Khanchych, 2019, s. 185).

Основними цілями тероризму в даний час є:

- дезорганізація державного управління і громадського порядку;

- створення загальної атмосфери хаосу і страху;

- нанесення політичного, економічного і морального збитку владі і населенню;

- дестабілізація ситуації в тій чи іншій країні або регіоні;

- припинення військових дій;

- провокування збройних конфліктів i зіткнень між групами населення на етноконфесійної або іншому грунті.

При цьому екстремісти часто не приховують, що вони такими методами намагаються змінити зовнішню і внутрішню політику окремих держав або групи країн (Ivanov, 2014).

Якщо говорити про політичні причин тероризму то серед них виділяють наступні:

- репресії правлячих еліт до опозиційних політичних партій;

- нав’язування правлячою елітою нетрадиційних соціально-політичних нововведень для даного суспільства;

- внутрішньополітичні конфлікти усередині самої держави;

- зіткнення політичних інтересів двох держав в якому-небудь регіоні;

- помилки уряду, які він допускає в національній політиці;

- цілеспрямоване розпалювання національної ворожнечі окремими людьми, групами, партіями (наприклад рух вахабітів);

- агресія викликана окупацією територій іншою державою, що здебільшого спричиняє озброєний опір мирного населення, яке 
використовує терористичні методи (вибухи важливих об’єктів, підпали і т. ін.);

- заохочення тероризму на рівні державної політики, як це роблять окремі країни;

- незадоволеність діяльністю уряду іноземних держав, що може призводити до терористичних актів проти його представників i установ (Shkurat, 2005, s. 5).

У деяких випадках мета терористичної діяльності може залишатися прихованою, а терористи оголошують інші «суміжні» цілі, які розраховані на підтримку певних верств населення, створення позитивного іміджу і сприяють досягненню реальної мети (Mokliak, 2016, s. 151).

Однією 3 головних обов'язкових умов сучасного тероризму $\epsilon$ резонанс терористичної акції у суспільстві. Глобальний характер цьому надають 3МІ, які миттєво передають повідомлення про терористичні акти, роблячи мільйони глядачів по всьому світу їх свідками і тим самим чинячи психологічний тиск на людей. Одночасно відбувається безкоштовна реклама терористичної організації, яка зазвичай не приховує своєї причетності для створення атмосфери страху і чинення тиску на владу. Непомічений або засекречений теракт втрачає всякий сенс (Koval’chyshyna, 2012).

Незважаючи на всі зусилля міжнародних організацій, провідних держав, інших країн і світового співтовариства в цілому, міжнародний тероризм поки не тільки не переможений, але i продовжує нарощувати масштаби своєї діяльності і все ширше поширюватися по планеті. Слідом за безпрецедентним за своїми масштабами терактом в США 2001 року хвиля терактів прокотилася по багатьох інших країнах. Ряд 3 них надовго поринули в терористичний хаос (Сирія, Ірак, Афганістан, Смен, Сомалі), інші піддаються потужним атакам міжнародних терористів епізодично (Індія, Пакистан, Судан, Кенія, Алжир, Малі, Нігерія, Лівія, Ліван, Єгипет), країни Європи також епізодично піддаються терористичним 
атакам (Великобританія, Іспанія, Франція Росія, Німеччина). Географія екстремістських акцій 3 кожним роком розширюється. Загальна кількість терористичних актів та їх жертв в світі неухильно зростає.

Після подій 11 вересня для багатьох розкрилися недоліки існуючих політичних i правових механізмів, що використовуються в боротьбі 3 міжнародним тероризмом. Це відсутність належної координації в роботі силових відомств усередині держав і на міжнародному рівні, неоднозначне ставлення різних суспільно-політичних сил у різних країнах до питання про походження сучасного тероризму і методи боротьби з ним (Shkurat, 2005, s. 6).

Сучасний тероризм - це достатньо складний феномен, який постійно еволюціонує. Його мотивація, механізми фінансування та підтримки, методи атаки та визначення цілей постійно змінюються і це значною мірою ускладнює ефективну стратегію протистояння цьому явищу. Це направду глобальна загроза, яка потребує глобальних протидій у відповідь. Причому ці дії повинні охоплювати витоки тероризму, його причинність і засоби запобігання цьому злочину, так i адекватні та результативні механізми боротьби з ним (Hromivchuk, 2011, s. 108).

Висновки i перспективи подальших досліджень. Проблеми тероризму i протидії йому сьогодні є одними 3 найважливіших як для окремих держав, так і для світової спільноти в цілому. Підсумовуючи все перелічене, слід зазначити, що сучасний тероризм, як складний політичний феномен, міняє свої засоби, форми і масштаби нападу, проте не міняє свою антилюдську суть, він досі є одним із найнебезпечніших феноменів, який не втратить своєї актуальності ще досить довго. Прояви тероризму i трансформація міжнародної ситуації змушують усвідомити глобальність того, що відбувається і прийняти той факт, що тероризм став не просто соціально-політичним явищем сучасності, а перетворився в особливу технологію залякування мас. А тому подальші наукові розвідки треба продовжувати у поглибленому дослідженні причин усунення цього 


\section{небезпечного явища та розробці нових методів та механізмів політичної}

боротьби з тероризмом.

\section{ЛIТЕРАТУРА:}

1. Громівчук, I. М., 2011. Міжнародноправове визначення тероризму як основа для ефективної боротьби 3 ним. Науковий вісник Інституту міжнародних відносин НАУ. Економіка, право, політологія, туризм, 2(4), с. 108-112.

2. Луппов, И. Ф., 2009. Политические аспекты дискуссии о сущности современного терроризма. Вестник Башкирского университета, 14(3), с. 944-948.

3. Мокляк, В. В., 2016. Сучасний тероризм як соціальне явище: сутність та форми прояву. Проблеми законності, 135, с. 147-156.

4. Рюміна, В. I., 2011. Інформаційний тероризм як інструмент зовнішньої політики держави на сучасному етапі. В: Україна в системі глобального інформаційного обміну: теоретикометодологічні аспекти дослідження $i$ підготовки фахівиів: Всеукраїнська наукова конференція. Львів, Україна, 27 травень 2011 р. Львів: Видавництво Львівської політехніки.

5. Тимошенко, В. І., 2017. Тероризм як об'єкт політико-правового дослідження. Науковий вісник Національної академії внутрішніх справ, 3 (104), с. 289-298.

6. Шкурат, I. В., 2005. Глобальний тероризм: методичні підходи до вивчення. [online] Доступно: http://www.academy.gov.ua/ej/ej2/txts/polprav/05sivmpv.pdf [Дата звернення ]

7. Горбатенков, О. Е., 2018. Терроризм в современном мире. Молодой ученый, [online] 20(206), с. 46-47. Доступно: https://moluch.ru/archive/206/50091/ [Дата обращения 6 Ноябрь 2020].

8. Канцір, В. С., 2010. Сучасний та змістовний аспекти політичного тероризму. Часопис Киівського університету права. Кримінальне право та кримінологія, 2, с. 266-270.

9. Канцір, В. С., 2015. Тероризм як метод політичної боротьби (політичний тероризм). Вісник Національного університету «Львівська політехніка». Юридичні науки, [online] 824, с. 430-435. Доступно:

\section{REFERENCES:}

1. Hromivchuk, I. M., 2011. Mizhnarodnopravove vyznachennia teroryzmu iak osnova dlia efektyvnoi borot'by z nym. Naukovyj visnyk Instytutu mizhnarodnykh vidnosyn NAU. Ekonomika, pravo, politolohiia, turyzm, 2(4), s. 108-112.

2. Luppov, I. F., 2009. Politicheskie aspektyi diskussii o suschnosti sovremennogo terrorizma. Vestnik Bashkirskogo universiteta, 14(3), s. 944-948.

3. Mokliak, V. V., 2016. Suchasnyj teroryzm iak sotsial'ne iavysche: sutnist' ta formy proiavu. Problemy zakonnosti, 135, s. 147156.

4. Riumina, V. I., 2011. Informatsijnyj teroryzm iak instrument zovnishn'oi polityky derzhavy na suchasnomu etapi. V: Ukraina $v$ systemi hlobal'noho informatsijnoho obminu: teoretyko-metodolohichni aspekty doslidzhennia i pidhotovky fakhivtsiv: Vseukrains'ka naukova konferentsiia. L'viv, Ukraina, 27 traven' 2011 r. L'viv: Vydavnytstvo L'vivs'koi politekhniky.

5. Tymoshenko, V. I., 2017. Teroryzm iak ob'iekt polityko-pravovoho doslidzhennia. Naukovyj visnyk Natsional'noi akademii vnutrishnikh sprav, 3 (104), s. 289-298.

6. Shkurat, I. V., 2005. Hlobal'nyj teroryzm: metodychni pidkhody do vyvchennia. [online] Dostupno:

http://www.academy.gov.ua/ej/ej2/txts/polprav/05sivmpv.pdf [Data zvernennia 6 Noyabr 2020]

7. Gorbatenkov, O. E., 2018. Terrorizm v sovremennom mire. Molodoy uchenyiy, [online] 20(206), s. 46-47. Dostupno: https://moluch.ru/archive/206/50091/ [Data obrascheniya 6 Noyabr 2020].

8. Kantsir, V. S., 2010. Suchasnyj ta zmistovnyj aspekty politychnoho teroryzmu. Chasopys Kyivs'koho universytetu prava. Kryminal'ne pravo ta kryminolohiia, 2, s. 266-270.

9. Kantsir, V. S., 2015. Teroryzm iak metod politychnoi borot'by (politychnyj teroryzm). Visnyk Natsional'noho universytetu «L'vivs'ka politekhnika». Yurydychni nauky, [online] 824, s. 430-435. Dostupno: http://nbuv.gov.ua/UJRN/vnulpurn_2015_82 4_71 [Data zvernennia 5 Lystopad 2020].

10. Shachkovs'ka, L. S. ta Khudajkulova, A., 
http://nbuv.gov.ua/UJRN/vnulpurn_2015_824 71 [Дата звернення 5 Листопад 2020]

10. Шачковська, Л. С. та Худайкулова, А., 2017. Інформаційний тероризм як феномен сучасної міжнародної політики. Вісник украӥнсько-туркменського культурноосвітнього центру, 1(II), с. 115-124.

11. Ханчич, В. В., 2019. Особливості розвитку сучасного тероризму. В: Актуальні дослідження правових та економічних процесів в контексті євроінтеграції: Матеріали Всеукраїнської науковопрактичної конференції. Дніпро, Україна, 28 Травень 2019. Дніпро: ДДУВС.

12. Иванов, С., 2014. Международный терроризм: причины его возникновения и меры противодействия. Зарубежное военное обозрение, 2, с. 8-13.

13. Ковальчишина, Н. I., 2012. Тероризм: теоретичний та праксеологічний аспекти проблеми. Вісник Національного університету оборони України, [online] 4, с. 158-163. Доступно: http://nbuv.gov.ua/UJRN/Vnaou_2012_4_34 [Дата звернення 05 Листопад 2020]

14. Ольшанский, Д. 2002. Психология терроризма. СПб.: Питер.
2017. Informatsijnyj teroryzm iak fenomen suchasnoi mizhnarodnoi polityky. Visnyk ukrains'ko-turkmens'koho kul'turnoosvitn'oho tsentru, 1(II), s. 115-124.

11. Khanchych, V. V., 2019. Osoblyvosti rozvytku suchasnoho teroryzmu. V: Aktual'ni doslidzhennia pravovykh ta ekonomichnykh protsesiv $v$ konteksti ievrointehratsii: Materialy Vseukrains'koi naukovopraktychnoi konferentsii. Dnipro, Ukraina, 28 Traven' 2019. Dnipro: DDUVS.

12. Ivanov, S., 2014. Mezhdunarodnyiy terrorizm: prichinyi ego vozniknoveniya i meryi protivodeystviya. Zarubezhnoe voennoe obozrenie, 2, s. 8-13.

13. Koval'chyshyna, N. I., 2012. Teroryzm: teoretychnyj ta prakseolohichnyj aspekty problemy. Visnyk Natsional'noho universytetu oborony Ukrainy, [online] 4, s. 158-163. Dostupno: http://nbuv.gov.ua/UJRN/Vnaou_2012_4_34 [Data zvernennia 05 Lystopad 2020]

14. Olshanskiy, D. 2002. Psihologiya terrorizma. SPb.: Piter.

\section{Інформація про авторів}

Данько Юрій Анатолійович - кандидат політичних наук, викладач кафедри політології, соціології і культурології Харківського національного педагогічного університету імені Г.С. Сковороди; e-mail: yuriyd86@gmail.com; ORCID: http://orcid.org/0000-0003-3544-5328.

Білоцерківська Наталя Геннадіївна - кандидат педагогічних наук, доцент, доцент кафедри політології, соціології і культурології Харківського національного педагогічного університету імені Г.С. Сковороди; e-mail: nataliya_belotserovskaya@ukr.net.; ORCID: http://orcid.org/0000-0002-9418-268X.

Стаття надійшла до редакції: 07.11.2020 р. $\quad$ Прийнята до друку: 26.11.2019 p. 